\title{
Surface Recombination Concept as Applied to Determinate Silicon Solar Cell Base Optimum Thickness with Doping Level Effect
}

\author{
Masse Samba Diop"1, Hamet Yoro Ba ${ }^{2}$, Ndeye Thiam², Ibrahima Diatta ${ }^{1}$, Youssou Traore ${ }^{1}$, \\ Mamadou Lamine Ba², El Hadji Sow ${ }^{1}$, Oulymata Mballo', Grégoire Sissoko ${ }^{1}$ \\ ${ }^{1}$ Laboratory of Semiconductors and Solar Energy, Physics Department, Faculty of Science and Technology, University Cheikh \\ Anta Diop, Dakar, Senegal \\ ${ }^{2}$ Laboratory of Sciences and Techniques of Water and Environment, Polytechnic School of Thiès, Thiès, Senegal \\ Email: gsissoko@yahoo.com
}

How to cite this paper: Diop, M.S., Ba, H.Y., Thiam, N., Diatta, I., Traore, Y., Ba, M.L., Sow, E.H., Mballo, O. and Sissoko, G. (2019) Surface Recombination Concept as Applied to Determinate Silicon Solar Cell Base Optimum Thickness with Doping Level Effect. World Journal of Condensed Matter Physics, 9, 102-111.

https://doi.org/10.4236/wjcmp.2019.94008

Received: August 26, 2019

Accepted: October 6, 2019

Published: October 9, 2019

Copyright $\odot 2019$ by author(s) and Scientific Research Publishing Inc. This work is licensed under the Creative Commons Attribution International License (CC BY 4.0).

http://creativecommons.org/licenses/by/4.0/

\begin{abstract}
New expressions of back surface recombination of excess minority carriers in the base of silicon solar are expressed dependent on both, the thickness and the diffusion coefficient which is in relationship with the doping rate. The optimum thickness thus obtained from the base of the solar cell allows the saving of the amount of material needed in its manufacture without reducing its efficiency.
\end{abstract}

\section{Keywords}

Silicon Solar Cell, Surface Recombination Velocity, Diffusion Coefficient, Doping Rate, Base Thickness

\section{Introduction}

The quality control of the solar cell aims at optimizing the various stages of its manufacture through, the doping rate respectively in the emitter and the base $(\mathrm{Nb}(\mathrm{D}))$, the crystallinity of the material and its orientation, as well as the thicknesses [1] [2] [3] [4] [5]. These different parameters influence the volume and surface recombination of the minority carrier [6] [7] in the solar cell.

Thus the recombination of the minority carrier is located:

$>$ in the volume, through the lifetime $(\tau)$ and the diffusion length $(L)$ connected by the relation of Einstein [8];

$>$ on the emitter-base (junction) surface [9] [10], which indicates the operating point (from open circuit to short circuit) [11] [12];

$>$ at the back of the base (p/p+) [13] [14] [15] [16]; 
at the grain boundaries in the 3D model [17] [18]. The aim is to uncouple the recombination of the minority carrier in the volume, from that appearing on the surfaces [19].

The recombination of the minority charge carrier is studied in order to evaluate their effect on the current response or voltage of the solar cell, under different conditions:

of illumination wavelength [20] [21] and illumination level $n$ [22] [23] [24] or under dark [25];

$>$ of operating mode in particular, in static regime [26], the dynamic frequency regime [27] or transient dynamic regime [28] [29] [30]);

of external action by applied electromagnetic field [31] [32], or irradiation of nuclear particles [12] or a change in temperature [33];

In this work, the phenomenological parameters, such as the recombination velocity of the minority carrier in volume $(\tau)$, at the emitter-base junction $(S f)$ and at the rear face $(S b)$ of the thickness base $(H)$, are studied. The optimum thickness $(H)$ of the silicon solar cell base leading to the maximum short circuit current is determined according to the doping rate $N b(D)$, for a low level of illumination $n$.

\section{Theory}

Figure 1 represents a silicon solar cell of type $\mathrm{n}^{+}-\mathrm{p}-\mathrm{p}^{+}$under polychromatic illumination [34] [35]. The space charge region $(x=0)$ constitutes the junction $\left(\mathrm{n}^{+}-\mathrm{p}\right)$, allowing the separation of photogenerated electron-hole pairs, subjected to a velocity $(S f)$, called recombination velocity at the junction [9] [10] [11]. The rear face corresponds to a zone of higher doping rate $\left(\mathrm{p}^{+}\right)$, in $x=H$, produces an electric field (back surface field), which allows the return of the minority carrier towards the junction, and characterized by a recombination velocity $(S b)$ [10] [16] [20].

When the solar cell is under illumination, the density of the photogenerated carrier in the base is governed by the following continuity equation:

$$
D \frac{\partial^{2} \delta(x)}{\partial x^{2}}-\frac{\delta(x)}{\tau}=-G(x)
$$

$\tau$ and $D$ are, respectively, the lifetime and the diffusion coefficient of excess minority carrier in the base, connected by the relation of Einstein.

$$
L^{2}(N b)=D(N b) \cdot \tau(N b)
$$

with $L$ the diffusion length of the minority carriers in excess. The diffusion coefficient and the lifetime of the excess minority carrier are related to the doping rate of the base $\left(\mathrm{Nb}\right.$ in $\left.\mathrm{cm}^{-3}\right)$ by the following empirical relations [36] [37]:

$$
\begin{gathered}
D(N b)=\frac{1350 \cdot V_{T}}{\sqrt{1+\frac{81 \cdot N b}{N b+3.2 \times 10^{-18}}}}\left(\mathrm{~cm}^{2} / \mathrm{s}\right) \\
V_{T}=\frac{k_{b} \cdot T}{q}
\end{gathered}
$$




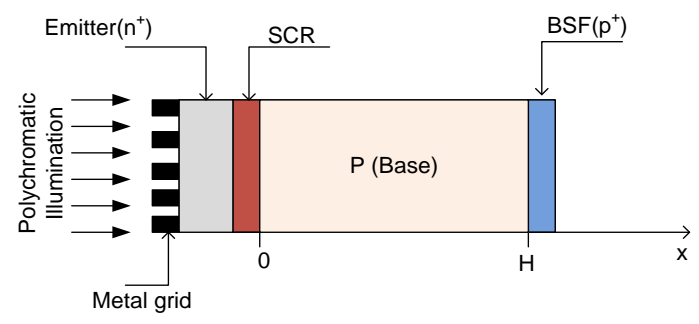

Figure 1. Structure of a solar cell of type $\left(n^{+}-p-p^{+}\right)$ illuminated by the emitter.

$T$ is the temperature of the solar cell, $k_{b}=1.43 \times 10^{-23} \mathrm{~m}^{2} \cdot \mathrm{kg} \cdot \mathrm{s}^{-2} \cdot \mathrm{K}^{-1}$ is the Boltzmann constant and $q=1.6 \times 10^{-19} \mathrm{C}$ the elementary charge.

$$
\tau(N b)=\frac{12}{1+\frac{N b}{5 \times 10^{16}}}(\mu \mathrm{s})
$$

$\delta(x)$ is the density of photogenerated carrier in the base, it is produced by the generation rate [38], expressed by the following equation:

$$
G(x)=n \sum_{i=1}^{3} a_{i} \mathrm{e}^{-b_{i} x}
$$

where $n$ is the number of sun or level of illumination, indicating the concentration of light [39].

$a_{i}$ and $b_{i}$ are coefficients obtained from the modeling of the radiation under A.M.1.5

The expression of the density of the minority carrier of charge in excess in the base is given by the resolution of the continuity equation and is written:

$$
\begin{aligned}
& \delta(x, S f, n, H, D) \\
& =A(S f, n, H, D) \cdot \cosh \left(\frac{x}{L(D)}\right)+B(S f, n, H, D) \cdot \sinh \left(\frac{x}{L(D)}\right) \\
& +\sum_{i=1}^{3} K(n, D) \cdot \mathrm{e}^{-b_{i} x} \\
& K(n, D)=\frac{n a_{i} \cdot L^{2}(D)}{D\left[1-\left(L(D) \cdot b_{i}\right)^{2}\right]}
\end{aligned}
$$

$A$ and $B$ are coefficients determined from the boundary conditions which respectively introduce the recombination velocity of the minority charge carrier at the junction $(S f)$ and at the rear face $(S b)[40]$.

- at the junction $(x=0)$

$$
\left.\frac{\partial \delta(x, S f, n, H, D)}{\partial x}\right|_{x=0}=S f * \delta(0, S f, n, H, D)
$$

- at the back surface $(x=H)$ :

$$
\left.\frac{\partial \delta(x, S f, n, D)}{\partial x}\right|_{x=H}=-S b * \delta(H, S f, n, D)
$$

$S f$ represents the recombination velocity of the carriers across the junction. $S b$ is the recombination velocity of minority carrier at the back surface [25] [26] 
[28].

In $\mathrm{x}-\mathrm{H}$, where there is a rear electric field $\left(\mathrm{p} / \mathrm{p}^{+}\right.$, low-high junction), which returns electrical charges, towards the junction (SCR), to be collected. The first solar cells did not have this technology, therefore the contact was ohmic type, and the recombination velocity $S b$ then, was very high. At this surface where there is a potential barrier, a part of the minority carrier can cross this junction $\mathrm{p} / \mathrm{p}^{+}$ [34].

\section{Results and Discussions}

\subsection{Photocurrent Density}

The expression of photocurrent density is given by Fick's law.

$$
\begin{aligned}
\operatorname{Jph}(S f, n, H, D) & =\left.q D * \frac{\partial \delta(x, S f, n, H, D)}{\partial x}\right|_{x=0} \\
& =q D\left[\frac{B(S f, n, H, D)}{L(D)}-\sum_{i=1}^{3} b_{i} K(n, D)\right]
\end{aligned}
$$

From Expression (8), we represent in Figure 2 the profile of the photocurrent density as a function of the recombination velocity of the minority carrier at the junction for different thickness values at constant level of illumination.

For values of $S f<10^{2} \mathrm{~cm} / \mathrm{s}$, the photocurrent is practically zero, which corresponds to an open circuit operating point of the solar cell. For the recombination velocity range from $10^{2} \mathrm{~cm} / \mathrm{s}$ to about $10^{4}$ or $10^{5} \mathrm{~cm} / \mathrm{s}$, the photocurrent increases. Beyond $10^{5} \mathrm{~cm} / \mathrm{s}$, the photocurrent is virtually constant with increasing $S f$ and corresponds to the short circuit current Jphsc. It increases with the level of illumination.

Now we represent in Figure 4 the profile of the photocurrent density as a function of the recombination velocity at the junction for different diffusion coefficients.

\subsection{The Recombination Velocity in Back Surface}

Figures 2-4 indicate a plateau regardless the values of, $D, H$, and $n$. Thus the derivative of the expression of the photocurrent density with respect to the recombination velocity vanishes [10] [13] [17] [26] and is written as:

$$
\frac{\partial J p h(S f, n, H, D)}{\partial S f}=0
$$

The resolution of this equation leads to the expressions of $S b 1\left(b_{i}, H, D\right)$ and $S b 2(H, D)$ the recombination velocity at the back face.

$$
\operatorname{Sb1}(H, D)=\sum_{i=1}^{3} \frac{D *\left[b_{i}\left(\cosh \left(\frac{H}{L(D)}\right)-\mathrm{e}^{-b_{i} H}\right)-\frac{1}{L(D)} \sinh \left(\frac{H}{L(D)}\right)\right]}{\cosh \left(\frac{H}{L(D)}\right)-\mathrm{e}^{-b_{i} H}-L b_{i} \sinh \left(\frac{H}{L(D)}\right)}
$$




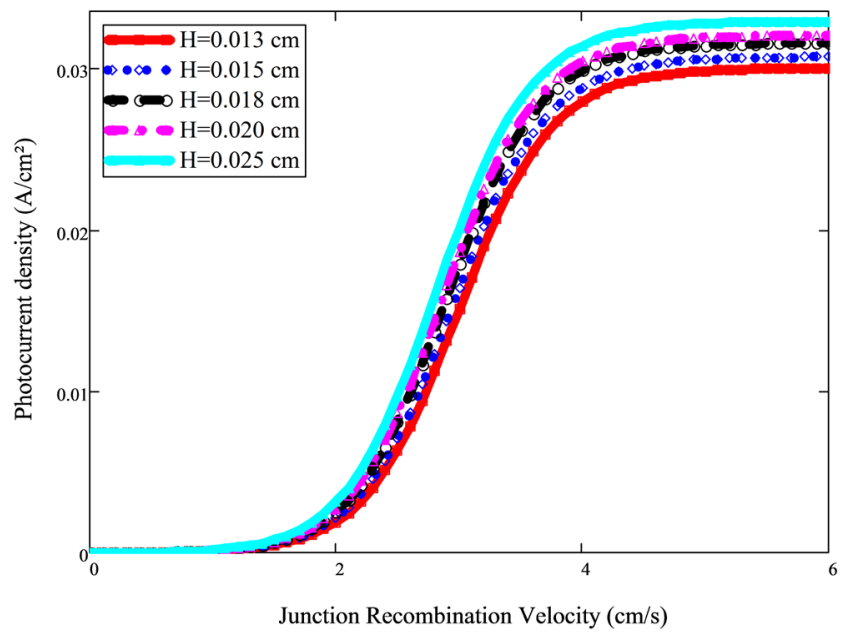

Figure 2. Photocurrent density as a function of the recombination velocity at the junction for different thickness values $\left(n=1.1, D=26 \mathrm{~cm}^{2} / \mathrm{s}\right)$.

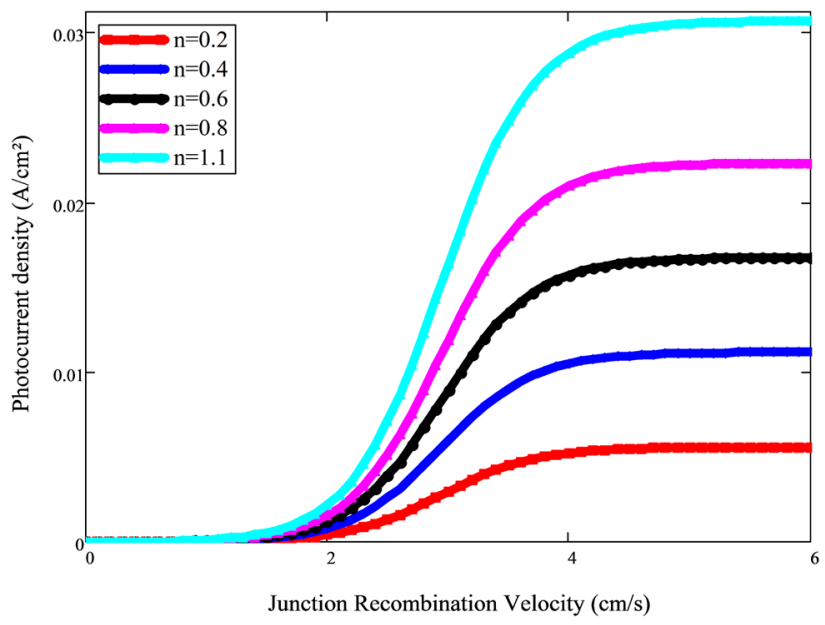

Figure 3. Photocurrent density as a function of the recombination velocity at the junction for different illumination levels, $H=0.0144 \mathrm{~cm}$.

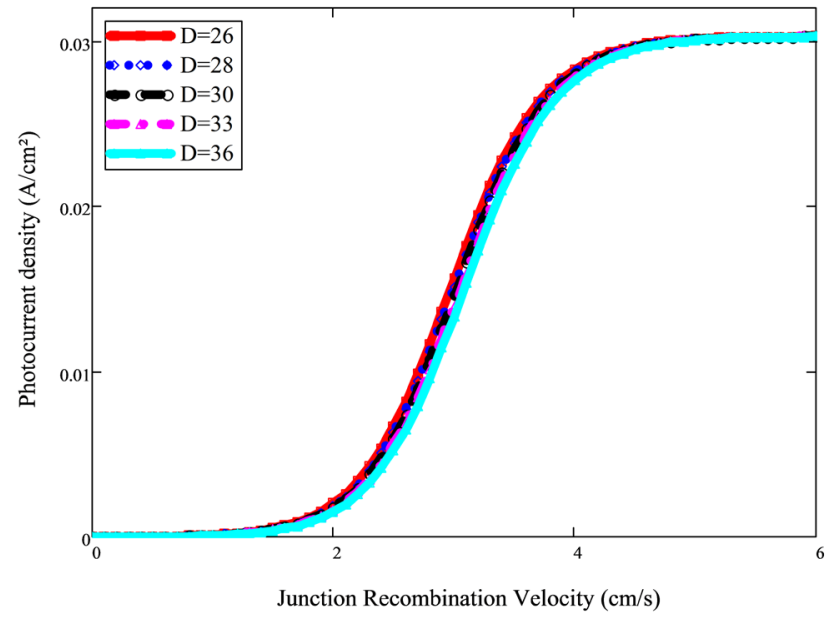

Figure 4. The profil of the photocurrent density as a function of the recombination velocity at the junction for different diffusion coefficients $(H=0.0144 \mathrm{~cm}, n=1.1)$. 
where appears the effect of the absorption of the light in the material through the coefficients $\left(b_{i}\right)$ and leads to a generation rate for $\left(b_{i} \cdot H \gg 1\right) . S b 1$ indicates the recombination velocity of the minority carrier sent back to the junction $\mathrm{n}^{+} / \mathrm{p}$, to participate in the photocurrent.

$$
\operatorname{Sb2}(H, D)=-\frac{D}{L(D)} * \tanh \left(\frac{H}{L(D)}\right)
$$

$S b 2<0$, indicates the flow of the minority carrier through the junction $\mathrm{p} / \mathrm{p}^{+}$ (FICK law), justifying the potential that introduces the electric field in the rear face [34]. It represents the intrinsic recombination velocity of the minority carrier at the $\mathrm{p} / \mathrm{p}^{+}$junction. The recombination velocity $S b 1$ and $S b 2$ yield an asymptote under the conditions where $H / L \gg 1$ and is equal to $D / L$, representing the diffusion rate [10] [13] [26].

Figure 5 gives the profile of the two expressions of recombination velocity at the rear face versus the solar cell base thickness, for different values of the diffusion coefficient of the minority carrier in the base.

The intercept point of the curves $S b 1$ and $S b 2$, gives the optimum thickness of the base of the solar cell, for each diffusion coefficient sought by other authors [41] assuming fixed rates of recombination.

Table 1 summarizes the variation in the thickness of the solar cell base for each diffusion coefficient and the respective short-circuit currents Jsc1 and Jsc2 which remain maximum and constant.

Figure 6 gives the representation of the thickness of the solar cell base necessary for each case of the diffusion coefficient.

The correlation between the diffusion coefficient and the optimum thickness of the base is established for $26 \mathrm{~cm}^{2} / \mathrm{s}<D<35 \mathrm{~cm}^{2} / \mathrm{s}$ :

$$
H(\mathrm{~cm})=[2 \cdot D(N b)+102] \cdot 10^{-4}
$$

It allows the realization of the silicon solar cell with Hopt thickness for a given doping of the base [42] [43].

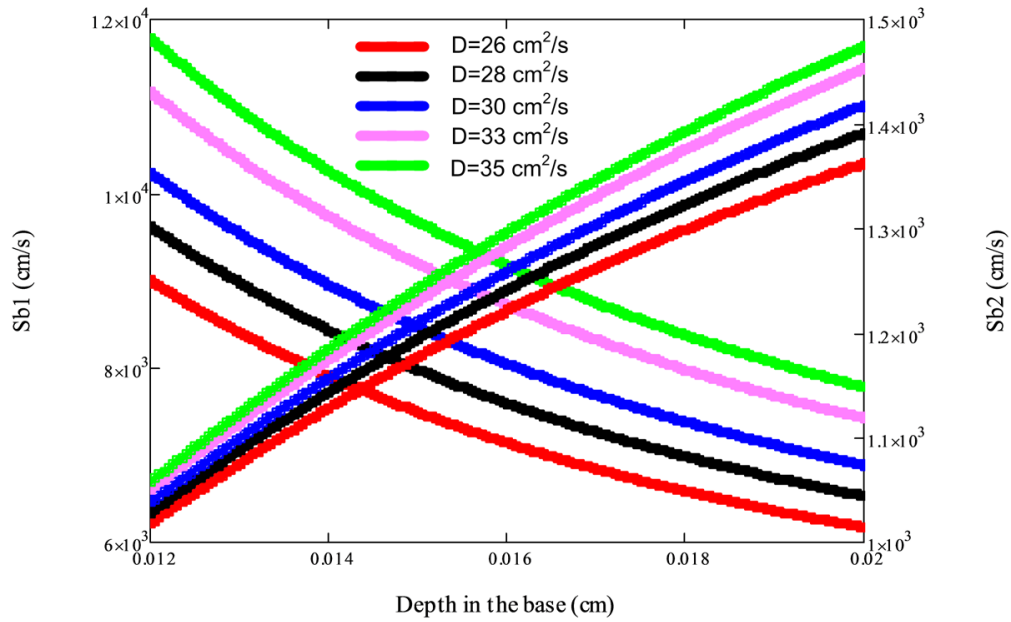

Figure 5. Recombination velocity at the back surface versus solar cell base thickness. 


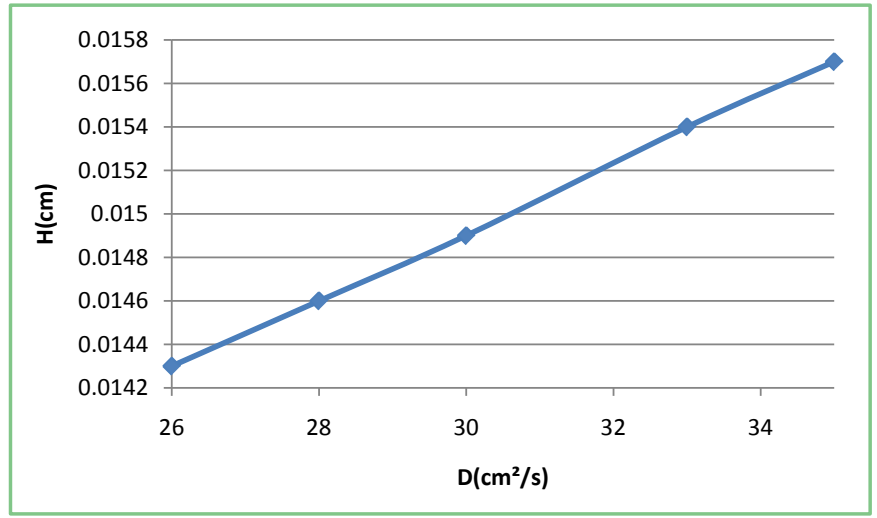

Figure 6. Depth $\mathrm{H}$ as a function of diffusion coefficient $D$.

Table 1. Thickness of the solar cell base, for different diffusion coefficients.

\begin{tabular}{cccccc}
\hline$N b\left(\mathrm{~cm}^{-3}\right)$ & $3.283 \times 10^{16}$ & $2.274 \times 10^{16}$ & $1.464 \times 10^{16}$ & $5.196 \times 10^{15}$ & $2.261 \times 10^{14}$ \\
\hline$D\left(\mathrm{~cm}^{2} / \mathrm{s}\right)$ & 26 & 28 & 30 & 33 & 36 \\
$H(\mathrm{~cm})$ & 0.0143 & 0.0146 & 0.0149 & 0.0154 & 0.0157 \\
$J s c 1\left(\mathrm{~A} / \mathrm{cm}^{2}\right)$ & 0.03 & 0.031 & 0.031 & 0.031 & 0.031 \\
$J S C 2\left(\mathrm{~A} / \mathrm{cm}^{2}\right)$ & 0.038 & 0.038 & 0.038 & 0.038 & 0.038 \\
$S b 1(\mathrm{~cm})$ & 7734.9 & 8139.4 & 8505 & 9003 & 9386.9 \\
$S b 2(\mathrm{~cm})$ & 1144.6 & 11783 & 1208.7 & 1250.2 & 1282.2 \\
\hline
\end{tabular}

\section{Conclusion}

In this work, a method for determining the optimum thickness of the base of the silicon solar cell by the technique of the intercept curves of back surface recombination velocity is proposed. The calibration curves of the photocurrent as a function of the recombination velocity of minority carrier at the junction are represented for different levels of illumination, of the thickness of the base and for different diffusion coefficients of the minority carrier. Thus, the back surface recombination velocity, dependent on both, the base thickness and the diffusion coefficient of the minority carrier, is deduced. The study of the profile of the recombination velocity of minority carrier on the back surface through these two expressions obtained, made it possible to establish the optimum thickness of the base, associated with a specific base doping rate, leading to a high short-circuit current, through a mathematical correlation, which leads to the economy of material in the manufacture of the solar cell and consequently the reduction of selling prices.

\section{Conflicts of Interest}

The authors declare no conflicts of interest regarding the publication of this paper.

\section{References}

[1] Honma, N. and Munakata, C. (1987) Sample Thickness Dependence of Minority 
Carrier Lifetimes Measured Using an Ac Photovoltaic Method. Japanese Journal of Applied Physics, 26, 2033-2036. https://doi.org/10.1143/JJAP.26.2033

[2] Cuevas, A., Fossum, J.G. and Young, R.T. (1985) Influence of the Dopant Density Profile on Minority-Carrier Current in Shallow, Heavily Doped Emitters of Silicon Bipolar Devices. Solid-State Electronics, 28, 247-254. https://doi.org/10.1016/0038-1101(85)90005-X

[3] Misiakos, K. and Tsamakis, D. (1994) Electron and Hole Mobilities in Lightly Doped Silicon. Applied Physics Letters, 64, 2007-2009. https://doi.org/10.1063/1.111721

[4] Lovejoy, M.L., Melloch, M.R., Ahrenkiel, R.K. and Lundstrom, M.S. (1992) Measurement Considerations for Zero-Field Time-of-Flight Studies of Minority Carrier Diffusion in III-V Semiconductors. Solid-State Electronics, 35, 251-259. https://doi.org/10.1016/0038-1101(92)90229-6

[5] Ducas, J. (1994) 3D Modelling of a Reverse Cell Made with Improved Multicrystalline Silicon Wafer. Solar Energy Materials \& Solar Cells, 32, 71-88. https://doi.org/10.1016/0927-0248(94)90257-7

[6] Mott, N.F. (1978) Recombination: A Survey. Solid-State Electronics, 21, 1275-1280. https://doi.org/10.1016/0038-1101(78)90192-2

[7] Neugroschel, A. (1981) Determination of Lifetimes and Recombination Currents in p-n Junction Solar Cells, Diodes, and Transistors. IEEE Transactions on Electron Devices, 29, 108-115. https://doi.org/10.1109/T-ED.1981.20290

[8] De Vischere, P. (1986) Comment on G.J. Rees. Surface Recombination Velocity-A Useful Concept. Solid-State Electronics, 29, 1161-1164.

https://doi.org/10.1016/0038-1101(86)90059-6

[9] Sissoko, G., Sivoththanam, S., Rodot, M. and Mialhe, P. (1992) Constant Illumination-Induced Open Circuit Voltage Decay (CIOCVD) Method, as Applied to High Efficiency Si Solar Cells for Bulk and Back Surface Characterization. 11 th European Photovoltaic Solar Energy Conference and Exhibition, Montreux, 352-354.

[10] Bocande, Y.L.B., Correa, A., Gaye, I., Sow, M.L. and Sissoko, G. (1994) Bulk and Surfaces Parameters Determination in High Efficiency Si Solar Cells. Renewable Ener$g y, 5,1698-1700$.

[11] Wu, C.Y. and Shen, W.Z. (1980) The Open-Circuit Voltage of Back-Surface-Field (BSF) $p$ - $n$ Junction Solar Cells in Concentrated Sunlight. Solid-State Electronics, 23, 209-216. https://doi.org/10.1016/0038-1101(80)90004-0

[12] Ndiaye, E.H., Sahin, G., Thiam, A., Dieng, M., Ly Diallo, H., Ndiaye, M. and Sissoko, G. (2015) Study of the Intrinsic Recombination Velocity at the Junction of Silicon Solar under Frequency Modulation and Irradiation. Journal of Applied Mathematics and Physics, 3, 1522-1535. https://doi.org/10.4236/jamp.2015.311177

[13] Sissoko, G., Nanéma, E., Ndiaye, A.L., Bocandé, Y.L.B. and Adj, M. (1996) Minority Carrier Diffusion Length Measurement in Silicon Solar Cell under Constant White Bias Light. Renewable Energy, 3, 1594-1597.

[14] Dhariwal, D.R. and Gadre, R. (1983) Modified Drift Field Model for High-Low Transition in Solar Cells. Solid-State Electronics, 26, 1083-1088. https://doi.org/10.1016/0038-1101(83)90006-0

[15] Hauser, J.R. and Dunbar, P.M. (1975) Minority Carriers Reflecting Properties of Semiconductor High-Low Junctions. Solid-State Electronics, 18, 715-716. https://doi.org/10.1016/0038-1101(75)90144-6

[16] Fossum, J.G. (1977) Physical Operation of Back-Surface-Field Silicon Solar Cells. 
IEEE Transactions on Electron Devices, 2, 322-325.

https://doi.org/10.1109/T-ED.1977.18735

[17] Ly Diallo, H., Maiga, A.S., Wereme, A. and Sissoko, G. (2008) New Approach of Both Junction and Back Surface Recombination Velocity in a 3D Modelling Study of a Polycrystalline Silicon Solar Cell. The European Physical Journal Applied Physics, 42, 203-211. https://doi.org/10.1051/epjap:2008085

[18] El Ghitani, H. and Martinuzzi, S. (1989) Influence of Dislocations on Electrical Properties of Large Grained Polycrystalline Silicon Cells. Journal of Applied Physics, 66, 1717-1726. https://doi.org/10.1063/1.344392

[19] Zondervan, A., Verhoef, L.A. and Lindholm, F.A. (1988) Measurement Circuits for Silicon-Diode and Solar Cells Lifetime and Surface Recombination Velocity by Electrical Short-Circuit Current Delay. IEEE Transactions on Electron Devices, 35, 85-88. https://doi.org/10.1109/16.2419

[20] Sissoko, G., Museruka, C., Corréa, A., Gaye, I. and Ndiaye, A.L. (1996) Light Spectral Effect on Recombination Parameters of Silicon Solar Cell. Renewable Energy, 3, 1487-1490.

[21] Flohr, T. and Helbig, R. (1989) Determination of Minority-Carrier Lifetime and Surface Recombination Velocity by Optical-Beam-Induced-Current Measurements at Different Light Wavelengths. Journal of Applied Physics, 66, 3060-3065. https://doi.org/10.1063/1.344161

[22] Murti, M.R. and Reddy, K.V. (1991) Recombination Properties of Photogenerated Minority Carriers in Polycrystalline Silicon. Journal of Applied Physics, 70, 3683-3688. https://doi.org/10.1063/1.349217

[23] Dhariwal, S.R., Mathur, R.K., Mehrotra, D.R. and Mittal, S. (1983) The Physics of p-n Junction Solar Cells Operated under Concentrated Sunlight. Solar Cells, 8, 137-155. https://doi.org/10.1016/0379-6787(83)90089-3

[24] Oualid, J. and Singal, C.M. (1984) Influence of Illumination on the Grain Boundaries Recombination Velocity in Silicon. Journal of Applied Physics, 55, 1195-1205. https://doi.org/10.1063/1.333161

[25] Rose, B.H. and Weaver, H.T. (1983) Determination of Effective Surface Recombination Velocity and Minority-Carrier Lifetime in High-Efficiency Si Solar Cells. Journal of Applied Physics, 54, 238-247. https://doi.org/10.1063/1.331693

[26] Diasse, O., Diao, A., Ly, I., Diouf, M.S., Diatta, I., Mane, R., Traore, Y. and Sissoko, G. (2018) Back Surface Recombination Velocity Modeling in White Biased Silicon Solar Cell under Steady State. Journal of Modern Physics, 9, 189-201. https://doi.org/10.4236/jmp.2018.92012

[27] Gueye, M., Ly Diallo, H., Moustapha, A.M., Traore, Y., Diatta, I. and Sissoko, G. (2018) Ac Recombination Velocity in a Lamella Silicon Solar Cell. World Journal of Condensed Matter Physics, 8, 185-196. https://doi.org/10.4236/wjcmp.2018.84013

[28] Lindholm, F.A., Liou, J.J., Neugroschel, A. and Jung, T.W. (1987) Determination of Lifetime and Surface Recombination Velocity of p-n Junction Solar Cells and Diodes by Observing Transients IEEE Transactions on Electron Devices, 34, 277-283. https://doi.org/10.1109/T-ED.1987.22919

[29] Kunst, M., Muller, G., Schmidt, R. and Wetzel, H. (1988) Surface and Volume Decay Processes in Semiconductors Studied by Contactlesss Transient Photoconductivity Measurements. Applied Physics, 46, 77-85.

https://doi.org/10.1007/BF00615912

[30] Barro, F.I., Seidou Maiga, A., Wereme, A. and Sissoko, G. (2010) Determination of Recombination Parameters in the Base of a Bifacial Silicon Solar Cell under Con- 
stant Multispectral Light. Physical and Chemical News, 56, 76-84.

[31] Diao, A., Wade, M., Thiame, M. and Sissoko, G. (2017) Bifacial Silicon Solar Cell Steady Photoconductivity under Constant Magnetic Field and Junction Recombination Velocity Effects. Journal of Modern Physics, 8, 2200-2208. https://doi.org/10.4236/jmp.2017.814135

[32] Ba, M.L., Ly Diallo, H., Ba, H.Y., Traore, Y., Diatta, I., Diouf, M.S., Wade, M. and Sissoko, G. (2018) Irradiation Energy Effect on an Illuminated Silicon Solar Cell: Maximum Power Point Determination. Journal of Modern Physics, 9, 2141-2155. http://www.scirp.org/journal/jmp https://doi.org/10.4236/jmp.2018.912135

[33] Singh, P., Singh, S.N., Lal, M. and Husain, M. (2008) Temperature Dependence of I-V Characteristics and Performance Parameters of Silicon Solar Cell. Solar Energy Materials \& Solar Cells, 92, 1611-1616. https://doi.org/10.1016/j.solmat.2008.07.010

[34] Burgess, F. and Lindholm, F.A. (1978) Silicon Solar Cell Designs Based on Physical Behavior in Concentrated Sunlight. Solid-State Electronics, 21, 729-737. https://doi.org/10.1016/0038-1101(78)90005-9

[35] Le Quang, N., Rodot, M., Nijs, J., Ghannam, M. and Coppye, J. (1992) Réponse spectrale de photopiles de haut rendement au silicium multicristallin. Journal de Physique III, 2, 1305-1316. https://doi.org/10.1051/jp3:1992108

[36] Fossum, J.G. (1976) Computer Aided-Numerical Analysis of Silicon Solar Cells. Solid-State Electronics, 19, 269-277. https://doi.org/10.1016/0038-1101(76)90022-8

[37] Fossum, J.G. and Lee, D.S. (1952) A Physical Model for the Dependence of Carrier Lifetime on Doping Density in Non-Degenerate Silicon. Solid-State Electronics, 15, 741-747. https://doi.org/10.1016/0038-1101(82)90203-9

[38] Furlan, J. and Amon, S. (1985) Approximation of the Carrier Generation Rate in Illuminated Silicon. Solid-State Electronics, 28, 1241-1243.

https://doi.org/10.1016/0038-1101(85)90048-6

[39] Jain, G.C., Singh, S.N. and Kotnala (1983) Diffusion Length Determination in $\mathrm{n}+\mathrm{pp}+$ Based Silicon Solar Cells from the Intensity Dependence of the Short Circuit for Illumination from the p+ Side. Solar Cells, 82, 39-48. https://doi.org/10.1016/0379-6787(83)90063-7

[40] Sissoko, G., Nanéma, E., Corréa, A., Biteye, P.M., Adj, M. and Ndiaye, A.L. (1998) Silicon Solar Cell Recombination Parameters Determination Using the Illuminated I-V Characteristic. Renewable Energy, 3, 1848-1851.

[41] Demesmaeker, E., Symons, J., Nijs, J. and Mertens, R. (1991) The Influence of Surface Recombination on the Limiting Efficiency and Optimum Thickness of Silicon Solar Cells. 10th European Photovoltaic Solar Energy Conference, Lisbon, 66-67. https://doi.org/10.1007/978-94-011-3622-8 17

[42] Meier, D.L., Hwang, J.M. and Campbell, B. (1988) The Effect of Doping Density and Injection Carrier Lifetime as Applied to Bifacial Dendrite Webs Silicon Solar Cell. IEEE Transaction on Electron Device, 35, 70-79. https://doi.org/10.1109/16.2417

[43] Guren, J.E., Del Alamo, J. and Luque, A. (1980) Optimization of p+ Doping Level of $\mathrm{n}+\mathrm{pp}+$ Bifacial BSF Solar Cells by Implantation. Electronics Letters, 16, 633-634. https://doi.org/10.1049/el:19800439 